\title{
Evaluation of nematocidal effects of some medicinal plant extracts against root-knot nematodes (Meloidogyne incognita)
}

\author{
Muhammad Ismail, ${ }^{1}$ Shahina Fayyaz, ${ }^{2}$ Attia Kowsar, ${ }^{1}$ Salma Javed, ${ }^{2}$ Iftikhar Ali, ${ }^{1}$ Sajjad Ali, ${ }^{1}$ \\ Farhad Hussain, ${ }^{1}$ Haibat Ali $^{3}$ \\ ${ }^{1}$ Department of Chemistry, Karakoram International University, Gilgit; ${ }^{2}$ National Nematological Centre, \\ University of Karachi, Karachi; ${ }^{3}$ Department of Environmental Sciences, Karakoram International \\ University, Gilgit, Pakistan
}

\begin{abstract}
Hundreds of highly toxic chemical pesticides and their conventional unsafe formulations of varying toxicities are used extensively to control pests, diseases, and weeds to increase agricultural production. The use of bio or botanical pesticides, which have been found effective, safe, and eco-friendly, could possibly provide a viable solution. Thus, the development and production of environment-friendly botanical pesticides and their water-based formulations, to replace the highly toxic agro-chemicals and unsafe formulations, has gained significant importance towards developing appropriate strategies for crop protection. The present study was aimed to evaluate the nematocidal nature of the aqueous extracts of Allium sativum, Urtica dioica, Sophora mollis, Ephedra intermedia, and Tanacetum baltistanicum. For this pur-
\end{abstract}

Correspondence: Muhammad Ismail, Department of Chemistry, Karakoram International University, University Road, Gilgit-15100, Pakistan.

Tel.: +92.345.3094385 - Fax: +92.5811.980039.

E-mail: dr.ismail@kiu.edu.pk

Key words: Green pesticides; Meloidogyne incognita; root-knot nematodes.

Funding: this work was supported by PhosAgro/UNESCO/IUPAC, Project NO. UNESCO-KIU 38 (contract No. 4500319945).

Contributions: MI, the main scientist to conduct and supervise the experimental work, draft preparation and project administration. Literature survey and writing original draft preparation. SF, SJ, nematocidal studies and statistical analysis. $\mathrm{AK}, \mathrm{FH}$, experimental work on the extraction and fractionation of plant extracts. IA, SA, reviewing and editing of the draft. HA, environmental aspects of the manuscript writing.

Conflict of interests: the authors declare no potential conflicts of interests.

Received for publication: 7 May 2019.

Revision received: 31 December 2019.

Accepted for publication: 1 January 2020.

(C) Copyright: the Author(s), 2020

Licensee PAGEPress, Italy

Italian Journal of Agronomy 2020; 15:1475

doi:10.4081/ija.2020.1475

This article is distributed under the terms of the Creative Commons Attribution Noncommercial License (by-nc 4.0) which permits any noncommercial use, distribution, and reproduction in any medium, provided the original author(s) and source are credited. pose, the plant material was dried in shade and mechanically ground into a powder form. The methanolic extracts of each plant sample were obtained and further extracted into different organic and aqueous fractions. The polar organic and aqueous fractions were further subjected to in vitro studies against Meloidogyne incognita, a common root-knot nematode. The results revealed that the polar organic and aqueous extracts of all the tested plants showed excellent results with total mortality of $75-95 \%$ at the concentrations of $0.125-1 \%$ after $72 \mathrm{~h}$ of the treatment. These results can be exploited further for their efficacy against $M$. incognita through on-field applications. The nematocidal effect of tested extracts indicates that some polar oxygenated secondary metabolites with lipophilic properties may be responsible to damage the cytoplasmic membrane of the nematode cells by interfering with the enzyme protein structure through their functional groups.

\section{Introduction}

Gilgit-Baltistan is rich in floral diversity and contains $70 \%$ of wild plant species. It is reported that $70-80 \%$ people in GilgitBaltistan use wild and domestic plants for the treatment of different diseases as well as crop protection (Khan et al., 2011). It is globally admired that pesticides are the best source of disease protection in plants (Hubert et al., 2013). Pesticides are the chemical substances having significant potential to resist insect growth that spoil or interfere with the growth of crops, shrubs, trees, timber, and other vegetation desired by humans. Synthetic pesticides contain harmful agents that pose long term danger to the human health and environment through their persistence in nature or body tissue. Many pesticides are poisonous in nature and are threat for living things being non-friendly to the environment, hence are useless (Nabile and Wakeil, 2013). The main purpose of using pesticides in agriculture is to protect crops from insects and to get better productivity (Jacobsen et al., 2015). Pesticides mainly dissolve in soil and undergo many chemical changes through a complex mechanism thus are used to treat plant diseases, destroy weeds, and inhibit insect-growth (Andrey and Pico, 2004). Previous study showed that before World War II people used both organic pesticides like pyrethrum, neem, nicotine, etc. and inorganic pesticides like sulphur, lead, copper, arsenic and lime (Kaberia, 2007). Some fifty years ago, synthetic pesticides provided a very safe means for crop protection worldwide but soon people realized their adverse effects on environment as well as on human health (Zadoks and Waibel, 2000). In 1940 when DDT, BHC and chlorinated cyclodienes were introduced, a great revolution came about in the world of agriculture as these chemical substances provided great agricultural productivity and protection. Over the time, the negative side 
effects of these synthetic chemicals like their residues on food etc. also came into account (Varma and Dubey, 1999). The use of organochlorine pesticides also causes ecological problems and are dangerous to human health due to their non-degradable properties (Martins et al., 2013). Since synthetic pesticides become a serious issue due to their toxic effects. Many other problems like effects on non-target organisms, non-biodegradability, and denatured-active components also weigh their importance (George et al., 2014). It is estimated that about three million people working in different field of agriculture around the world are affected by the toxicity of synthetic pesticides every year and around 20,000 people died due to direct use of agrochemicals. From the experiments, it is concluded that very small amount (less than 1\%) of pesticides used for crop protection affect the target organisms and the remaining can pollute soil, air, water, and food (Amoabeng et al., 2014).

Study of the human history showed that in every era human being depended on plants to fulfil their needs. Human used plants as a source of food, medicine, household tools, fuel, etc (Jabeen et al., 2015; Kumar and Simon, 2016). Globally medicinal plants received significant importance and provide financial support to the nations (Gilani et al., 2006). Plants contain vast number of biologically active compounds (Ujvary, 2000; Uy and Villazorda, 2015). A survey of World Health Organization reported that about $80 \%$ peoples in developing countries use drugs obtained from medicinal plants (Priya and Gopalan, 2015). Historically plants and their phytochemicals are the best source to control insects, nematodes, etc. (Dang et al., 2005). Medicinal plants take attention of researchers worldwide to use them as botanical pesticides and drugs due to their eco-friendly nature and nontoxic behaviour (Adebayo et al., 2014). Pesticides derived from plant sources are easily available, economical, harmless, and biodegradable (Tapwal et al., 2011). Plants contain repulsive aromatic substances which provide defence and work as repellents against insects (Kaberia 2007). It is reported that there are many plant species which have great potential in pesticide formulation used in integrated pest management (Sola et al., 2014).

The use of botanical pesticides has been introduced for hundreds of years for food preservation. Many kinds of plant derived products like essential oils, powder and plant are used as pesticides and to control insect's growth (Kedia et al., 2015). The active chemical compounds like proteins, oxalates, glycosides, terpenes, phenolic, alkaloids, anthocyanins etc. present in plants play major role in their defence mechanism (Priya and Gopalan, 2015). Biopesticides based on plants provide great methodology for crop protection. Secondary metabolites pay significant contribution to resist insect growth as they contain several phytochemicals such as flavonoid, monoterpenes, and organosulphur compounds (Zubari, 2006; Hubert et al., 2013). The secondary metabolites inhibit insect's growth by affecting their locomotion, feeding behaviour, oviposition, development, and physiological processes (Odeyemi, et al., 2013). Many plant species of the families like Rutaceae and Myrtaceae possess pesticidal activity and are used for insect control and are considered as botanical insecticides (Khan et al., 2014).

A variety of the management strategies for botanical based nematodes control has been adopted effectively to reduce the hazards of chemical nematicides to human and the environment. Identification of plant based nematicides has been considered a green approach, where many plants extracts, and its active compounds have been already discovered (Ahmad et al., 2010; Echeverrigaray et al., 2010; Chaudhary et al., 2013). In the present study, it is aimed to achieve the target of pest-control by using the plant extracts with nematocidal properties including Sophora mol- lis, Ephedra intermedia, Urtica dioica, Allium sativum and Tanacetum baltistanicum against Meloidogyne incognita, a rootknot nematode.

\section{Materials and methods}

\section{Collection of plant material}

Whole plants, each weighing $1-2 \mathrm{~kg}$ of $S$. mollis $(1.3 \mathrm{~kg}), U$. dioica $(1.1 \mathrm{~kg})$, E. intermedia $(1.4 \mathrm{~kg})$, A. sativum $(1.0 \mathrm{~kg})$, and $T$. baltistanicum $(1.9 \mathrm{~kg})$, were collected from different areas of Gilgit region namely Sonicot, Napora, Nomal, Danyor, and Sumayar respectively, in June 2016. The plants were identified by Dr. Sujjad Hyder, resident botanist, Department of Environmental Sciences, Karakoram International University, Gilgit.

\section{Preparation of the sample extracts}

The whole plant materials were dried in shade and ground separately. Each dried and ground plant material was soaked in enough methanol (95\%) for one week at room temperature with occasional shaking and stirring. The whole mixture was then filtered by using sheets of commercial grade filter paper. The filtrate obtained was evaporated by using rotatory evaporator to obtain solidified crude methanolic extract $(M E)$ of each plant sample. The soaking and extraction process were repeated three times.

\section{Fractionation process}

The crude methanolic extracts were then successively partitioned by solvent-solvent fractionation into four major fractions; methanol $(M E), n$-hexane $(H E)$, ethyl acetate $(E E)$, and aqueous extracts $(A E)$. The ethyl acetate fraction of $T$. baltistanicum was further fractionated by using liquid column chromatography into 11 fractions with gradient increase of ethyl acetate starting with $n$ hexane $(100 \%)$ as mobile phase. All the plant extracts of $S$. mollis (roots and stems), U. dioica, E. intermedia, A. sativum, and ethyl acetate fractions of $T$. baltistanicum were analysed further for their nematocidal activity against $M$. incognita by following standard protocol.

\section{Nematocidal activity}

The effect of 16 extracts was evaluated for larval mortality of root-knot nematode. Population of J2 infective stage juveniles of $M$. incognita was collected from pure culture maintained on tomato plants in microplot of a screen house in National Nematological Research Center, University of Karachi, Karachi, Pakistan. Eggmasses were extracted from the roots of infected tomato plant and transferred to small cavity block contained water. The cavity block was incubated for egg hatching at $28^{\circ} \mathrm{C}$ for 3 days. For nematocidal activity 100 larvae were counted in a counting chamber for each dose and replicated thrice to introduce in $3 \times 3$ glass cavity block. The stock solutions $(10 \mathrm{mg} / \mathrm{mL})$ from plant extracts were prepared in 5\% dimethyl sulfoxide (DMSO). Three concentrations $1 \%, 0.5 \%$ and $0.125 \%$ were applied at a rate of $1 \mathrm{~mL}$ at each cavity block. The synthetic nematicide furadan was taken as standard and $5 \%$ DMSO used as a control treatment for the comparison of results. Stereoscopic microscope was used after 24,48 and $72 \mathrm{~h}$ of intervals at magnification $4 \mathrm{x}$ to study the percent of mortality. Nematodes were considered dead when no movement was observed after mechanical nudge, their irreversible mobility was confirmed by transferring them to distilled water. 


\section{Statistical analysis}

Treatment differences were analysed by multifactor analysis of variance (ANOVA) and then the data sheet was subjected to Duncans' multiple range test (DMRT) $(\mathrm{P} \leq 0.05)$ using SPSS statistical software. Probit analysis was performed under survival analysis for $\mathrm{LC}_{50}$ values by SAS, 2000.

\section{Results}

In present study, the methanolic and aqueous extracts of roots, stems, and leaves of Sophora mollis and Urtica dioica whereas, roots and aerial parts of Ephedra intermedia and only bulbs of Allium sativum were evaluated as nematocidal agents. In addition to these, the hexanes, methanolic and ethyl acetate extracts of $T$. baltistanicum were also screened for its potential against root knot nematodes.

The aqueous bulbs extract of $A$. sativum showed highest mor- tality of M. incognita at the concentration (conc.) of $1 \%$ after $78 \mathrm{~h}$. The leaf (L) extract of Urtica dioica showed maximum mortality response (40-47\%) after $24 \mathrm{~h}$ of exposure as compared to the rest of the extracts studied during this study. The roots and stems (R, S) showed no mortality response after $24 \mathrm{~h}$ exposure (Table 1 ), while the leaf extract of $U$. dioica exhibited the surprising activity of 90 , 85 , and $82 \%$ after $72 \mathrm{~h}$ at $1,0.5$, and $0.125 \%$ conc., respectively. The $A E$ of roots and stems of Sophora mollis showed significant nematocidal activity against $M$. incognita at different concentrations. In case of $S$. mollis, the most active extract was that of the leaf parts after $72 \mathrm{~h}$ treatment with the activity of $88 \%$ larval mortality of $M$. incognita at $1 \%$ conc. (Table 1). The lethal dose concentrations $\left(\mathrm{LC}_{50}\right)$ values of tested aqueous extracts are given in Table 2. The tested extracts were found to exhibit varied nematocidal effects ranging from weak, moderate and strong as determined by $\mathrm{LC}_{50}$. The lowest $\mathrm{LC}_{50}$ observed for roots and stems extracts of $S$. mollis (0.039) and bulbs of A. sativum (0.032) against the common nematodes ( $M$. incognita). A low $\mathrm{LC}_{50}$ value is indicative of greater antinematode activity. The leaf extract of $S$. mollis had a $\mathrm{LC}_{50}$ value of 0.043 .

Table 1. Nematocidal effects of aqueous extracts (AE) of different plant species.

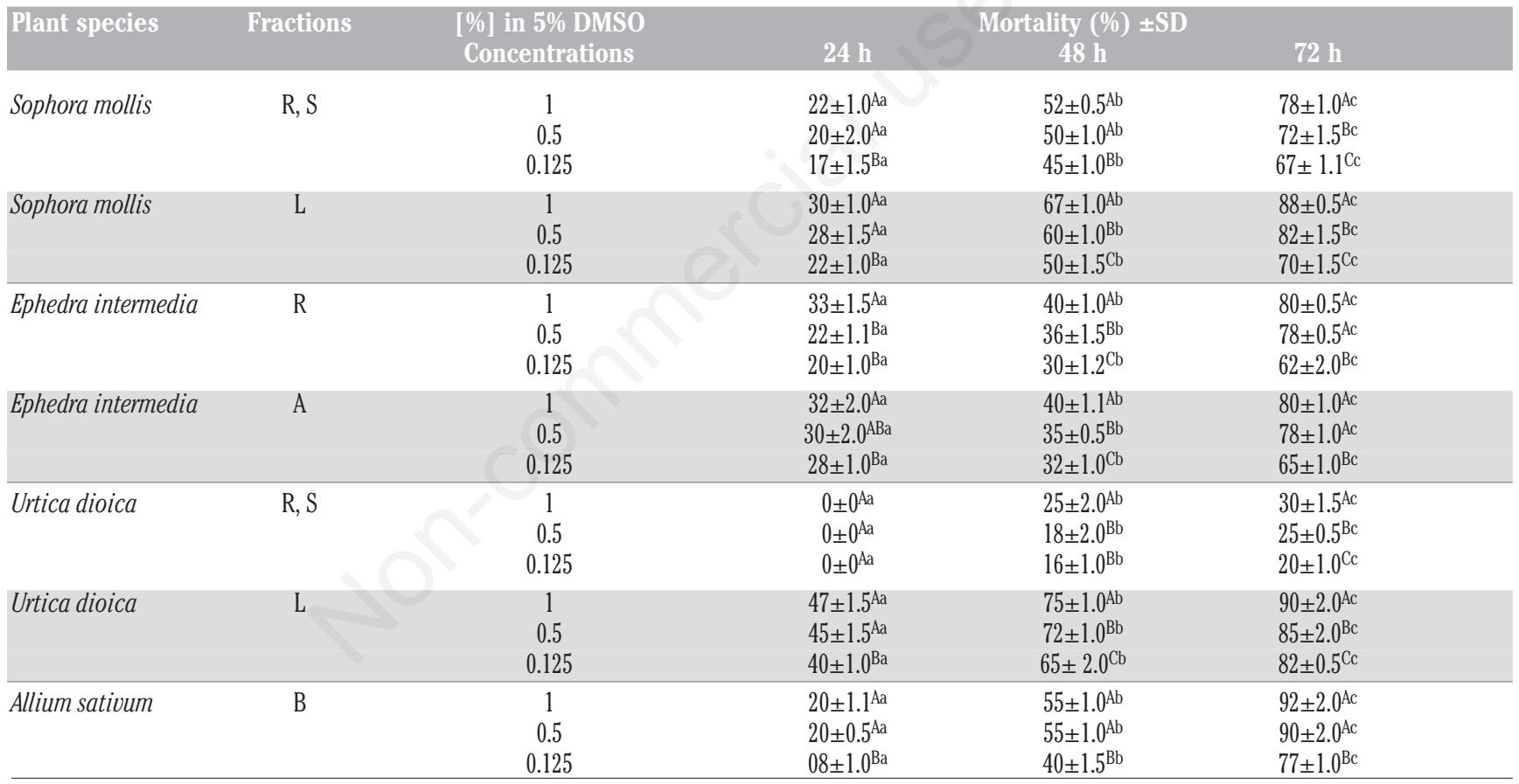

$\mathrm{R}$, roots; S, stems; L, leaves; A, aerial parts; B, bulbs. ${ }^{\mathrm{A}-\mathrm{C} V a l u e s}$ in columns having same upper-case letters are not significantly different $(\mathrm{P}<0.001)$; ${ }^{\mathrm{a}-\mathrm{CV}} \mathrm{Calues}$ in rows having same lower-case letters are not significantly different $(\mathrm{P}<0.001)$.

Table 2. Median lethal concentration $\left(\mathrm{LC}_{50}\right)$ of aqueous extracts of plant species.

\begin{tabular}{|c|c|c|c|}
\hline Plant species & $24 \mathrm{~h}$ & $\begin{array}{c}\mathrm{LC}_{50}(95 \% \mathrm{CL}) \\
48 \mathrm{~h}\end{array}$ & $72 \mathrm{~h}$ \\
\hline Sophora mollis (R, S) & $0.402(6.0903-3.4185)$ & $0.4194(2.0635-0.0002)$ & $0.0399(0.7963-0.0001)$ \\
\hline Sophora mollis (L) & $0.3019(3.8571-1.8506)$ & $0.1641(0.6235-0.0003)$ & $0.0435(0.0701-0.0003)$ \\
\hline Ephedra intermedia (R) & $0.1713(2.5447-1.4062)$ & 0.2693 (2.684-0.8939) & $0.0672(0.1024-0.0005)$ \\
\hline Ephedra intermedia (A) & $0.6256(6.6397-2.4817)$ & $0.3317(3.1406-0.9358)$ & $0.1711(0.0827-00.00)$ \\
\hline Urtica dioica $(\mathrm{R}, \mathrm{S})$ & - & $0.2174(3.5562-2.1114)$ & $0.2283(3.2012-1.6836)$ \\
\hline Urtica dioica (L) & $0.4145(2.6859-0.0003)$ & $0.0479(1.0699-0.0001)$ & $0.3745(0.0373-0.000)$ \\
\hline Allium sativum (B) & $0.1534(2.9404-1.921)$ & $0.3992(1.2093-0.1002)$ & $0.0329(0.0482-0.0001)$ \\
\hline
\end{tabular}


This result suggested that the effectiveness of aqueous extracts of $S$. mollis, A. sativum and roots extract of E. intermedia were closely similar to each other. The $\mathrm{LC}_{50}$ values of $0.17,0.22$, and 0.37 were recorded for aerial extract of $E$. intermedia and roots and stems and leaf extracts of $U$. dioica, respectively.

The observed nematocidal activity of the methanolic extract was 40 and $55 \%$ at $1 \%$ conc. after 24 and $48 \mathrm{~h}$, respectively with the total mortality of $95 \%$ and it is very close to the standard used during these experiments. Whereas, the larval mortality at the conc. of $0.5 \%$ was 40 and $54 \%$ after 24 and $48 \mathrm{~h}$, respectively with total activity of $92 \%$ mortality. The results remain very precise at all concentrations from $0.125-1 \%$ with minor increase in rate of mortality with the increasing concentrations. The aerial parts of Ephedra intermedia showed 45-74\% mortality after $72 \mathrm{~h}$ of the treatment for lowest to highest dose (Table. 3). The $\mathrm{LC}_{50}$ values of the methanolic extracts are given in Table 4.

The nematocidal activities of the hexanes, methanolic and the aqueous extracts of $T$. baltistanicum were more consistent at the conc. of $1,0.5$ and $0.125 \%$ with the total larval mortality of 70 $80 \%$ after $72 \mathrm{~h}$ of the exposure time. The EE of T. baltistanicum was further fractionated by using silica get column chromatography into 8 sub-fractions by using $10 \%$ gradient increase of ethyl acetate with $100 \%$ hexane as a mobile phase. Among these fractions, 3-sub-fractions eluted through silica gel column at 30, 50, and $80 \%$ of ethyl acetate in hexane showed excellent activity $(80 \%)$ after $72 \mathrm{~h}$ exposure at the conc. of $1 \%$ (Table 5). The $\mathrm{LC}_{50}$ values of different extracts and ethyl acetate fractions of $T$. baltistanicum are given in Table 6 . The hexanes extract showed the lowest $\mathrm{LC}_{50}(0.034)$ followed by $100 \%$ ethyl acetate extract and the aqueous extract $(0.077)$. The highest $\mathrm{LC}_{50}$ values were exhibited by $50 \%$ ethyl acetate extract and considered the least active fraction of $T$. baltistanicum against the nematodes of the $M$. incognita.

\section{Discussion}

The Meloidogyne incognita is a parasite, plant-damage causing nematodes. It is a widespread nematode found in all continents. Plants attacked by $M$. incognita are characteristically retarded and show slow performance in quality and quantity. Usually, synthetic nematicides are used for controlling these harmful nematodes. But the synthetic forms also affect non-target organisms. These synthetic nematicides may cause the problems of environmental pollution due to the degradation issues associated with the synthetic organic compounds. The botanical nematicides are more selective, eco-friendly, and locally produced as compared to synthetic ones. In current study, the nematocidal effects of different extracts of Sophora mollis, Ephedra intermedia, Urtica dioica, Allium sativum and Tanacetum baltistanicum against Meloidogyne incognita were discussed.

The effects of different extracts obtained from A. sativum, $U$. dioica, $S$. mollis, E. intermedia, and T. baltistanicum on larval mortality of root-knot nematode was determined after 20 min., 1, 2, 24, 48. and $72 \mathrm{~h}$ at different concentrations. According to the literature, Allium sativum has been used to control different insects. The ethyl acetate extract of the bulbs (B) shown effective resistance to Colletotrichum lindemuthianum (Masangwa et al., 2013). Nath and Singh, 2015 reported that aqueous extract of the bulbs of $A$. sativum has been used to control harmful insects in the fields. The aqueous and the ethanol extracts of $A$. sativum effectively controlled M. javania (Abbas, et al., 2009). Ferris and Zheng (1999) also reported the nematocidal activity of aqueous extract of $A$. sativum against $M$. javania. It has been revealed that $A$. sativum has great potential as an active pesticide due to the presence of an active chemical compound called diallyl sulphide (Tijjani et al., 2014). The chemical products obtained from A. sativum shows effective resistance against the different insect populations. In the field, T. urticae population was controlled by extract of $A$. sativum (Mackeen et al., 1997). In addition, A. sativum possesses antinematocidal (Attia et al., 2013), and antibacterial properties (Amonrar and Reeves, 1970). The present study is also in-line with the reported studies that $A$. sativum can be used as a potential pesticide to control different insect species whereas, its excellent activity against $M$. incognita is reported for the first time. In the present study, the $M E$, and $A E$ obtained from the bulbs of $A$. sativum showed the remarkable nematocidal activity. The methanolic extract of $A$. sativum showed more pronounced activity as compared to its aqueous extract. The results revealed that among all the tested plant extracts, A. sativum has maximum nematocidal activity against $M$. incognita (Tables 1 and 2).

Table 3. Nematocidal effects of methanolic extracts $(M E)$.

\begin{tabular}{|c|c|c|c|c|}
\hline Plant species & $\begin{array}{c}\text { [\%] in 5\% DMSO } \\
\text { Concentrations }\end{array}$ & $24 \mathrm{~h}$ & $\begin{array}{c}\text { ality (\%) } \\
48 \mathrm{~h}\end{array}$ & $72 \mathrm{~h}$ \\
\hline Allium sativum (B) & $\begin{array}{c}1 \\
0.5 \\
0.125\end{array}$ & $\begin{array}{l}40 \pm 1.1^{\mathrm{Aa}} \\
40 \pm 2.0^{\mathrm{Aa}} \\
30 \pm 1.0^{\mathrm{Ba}}\end{array}$ & $\begin{array}{l}55 \pm 0.5^{\mathrm{Ab}} \\
54 \pm 2.0^{\mathrm{Bb}} \\
50 \pm 2.0^{\mathrm{Cb}}\end{array}$ & $\begin{array}{l}95 \pm 1.5^{\mathrm{Ac}} \\
92 \pm 1.0^{\mathrm{Bc}} \\
90 \pm 1.0^{\mathrm{Bc}}\end{array}$ \\
\hline Ephedra intermedia (A) & $\begin{array}{c}1 \\
0.5 \\
0.125\end{array}$ & $\begin{array}{c}12 \pm 2.0^{\mathrm{Aa}} \\
05 \pm 1.5^{\mathrm{Ba}} \\
0 \pm 0^{\mathrm{Ca}}\end{array}$ & $\begin{array}{l}32 \pm 1.5^{\mathrm{Ab}} \\
25 \pm 1.5^{\mathrm{Bb}} \\
10 \pm 0.5^{\mathrm{Cb}}\end{array}$ & $\begin{array}{l}74 \pm 1.0^{\mathrm{Ac}} \\
50 \pm 1.0^{\mathrm{Bc}} \\
45 \pm 1.0^{\mathrm{Cc}}\end{array}$ \\
\hline
\end{tabular}

A-CValues in columns having same upper-case letters are not significantly different $(\mathrm{P}<0.001)$; ${ }^{\text {a-c }}$ Values in rows having same lower-case letters are not significantly different $(\mathrm{P}<0.001)$

Table 4. Median lethal concentration $\left(\mathrm{LC}_{50}\right)$ of methanolic extracts $(M E)$.

\begin{tabular}{|c|c|c|c|}
\hline Plant species & $24 \mathrm{~h}$ & $\begin{array}{c}\mathrm{LC}_{50}(95 \% \mathrm{CL}) \\
48 \mathrm{~h}\end{array}$ & $72 \mathrm{~h}$ \\
\hline Allium sativum B & $0.1383(1.312-0.3878)$ & $0.3414(3.7109-0.0042)$ & $0.3034(2.7505-0.000)$ \\
\hline Ephedra intermedia A & 3.4947 (28.6301-0.1166) & $0.0617(1.1223-0.71)$ & $0.9336(7.5147-0.0333)$ \\
\hline
\end{tabular}


Stinging nettle, Urtica dioica has been used as an active pesticide against Aphids. Previous study shows that aqueous extract of $U$. dioica was mostly used to control Aphids in preference to the synthetic pesticides (Kaberia 2007). Previous studies indicate that the aqueous extract of Urtica dioica shows antifungal activity against Alternaria solani, A. zinnia, Curvularia lunats, Rhizoctonia solani and Fusarium oxysporum (Tapwal et al., 2011). Moreover, the antifeedant property of $U$. dioica towards A. bipunctata has also been reported (Roy et al., 2016). Nassar, 2016 reported that $U$. urens showed prominent resistance to nematodes such as

Table 5. Nematocidal effects different extracts and ethyl acetate fractions of T. baltistanicum.

\begin{tabular}{|c|c|c|c|c|}
\hline Sample code & Conc. $\%$ & $24 \mathrm{~h}$ & $48 \mathrm{~h}$ & $72 \mathrm{~h}$ \\
\hline$H E$ & $\begin{array}{c}1 \\
0.5 \\
0.125\end{array}$ & $\begin{array}{l}18 \pm 0.5^{\mathrm{Aa}} \\
15 \pm 1.0^{\mathrm{Ba}} \\
12 \pm 1.0^{\mathrm{Ca}}\end{array}$ & $\begin{array}{l}42 \pm 2.0^{\mathrm{Ab}} \\
40 \pm 1.5^{\mathrm{Ab}} \\
35 \pm 1.5^{\mathrm{Bb}}\end{array}$ & $\begin{array}{l}80 \pm 0.5^{\mathrm{Ac}} \\
75 \pm 1.5^{\mathrm{Bb}} \\
70 \pm 1.1^{\mathrm{Cc}}\end{array}$ \\
\hline$A E$ & $\begin{array}{c}1 \\
0.5 \\
0.125\end{array}$ & $\begin{array}{l}22 \pm 1.0^{\mathrm{Aa}} \\
18 \pm 1.0^{\mathrm{Ba}} \\
15 \pm 2.0^{\mathrm{Ca}}\end{array}$ & $\begin{array}{l}50 \pm 1.5^{\mathrm{Ab}} \\
45 \pm 1.1^{\mathrm{Bb}} \\
42 \pm 1.0^{\mathrm{Cb}}\end{array}$ & $\begin{array}{l}82 \pm 1.0^{\mathrm{Ac}} \\
78 \pm 1.1^{\mathrm{Bc}} \\
65 \pm 1.0^{\mathrm{Cc}}\end{array}$ \\
\hline$M E$ & $\begin{array}{c}1 \\
0.5 \\
0.125\end{array}$ & $\begin{array}{l}20 \pm 1.1^{\mathrm{Aa}} \\
10 \pm 1.0^{\mathrm{Ba}} \\
08 \pm 1.5^{\mathrm{Ba}}\end{array}$ & $\begin{array}{l}48 \pm 2.0^{\mathrm{Ab}} \\
42 \pm 1.5^{\mathrm{Bb}} \\
40 \pm 1.0^{\mathrm{Bb}}\end{array}$ & $\begin{array}{l}80 \pm 1.5^{\mathrm{Ac}} \\
70 \pm 1.0^{\mathrm{Bc}} \\
57 \pm 1.0^{\mathrm{Cc}}\end{array}$ \\
\hline $20 \% E E$ & $\begin{array}{c}1 \\
0.5 \\
0.125\end{array}$ & $\begin{array}{l}30 \pm 1.0^{\mathrm{Aa}} \\
27 \pm 1.0^{\mathrm{Ba}} \\
25 \pm 0.5^{\mathrm{Ba}}\end{array}$ & $\begin{array}{l}45 \pm 1.5^{\mathrm{Ab}} \\
40 \pm 2.0^{\mathrm{Bb}} \\
35 \pm 1.0^{\mathrm{Cb}}\end{array}$ & $\begin{array}{l}58 \pm 1.5^{\mathrm{Ac}} \\
55 \pm 0.5^{\mathrm{Bc}} \\
47 \pm 1.0^{\mathrm{Cc}}\end{array}$ \\
\hline $30 \% E E$ & $\begin{array}{c}1 \\
0.5 \\
0.125\end{array}$ & $\begin{array}{l}32 \pm 1.0^{\mathrm{Aa}} \\
30 \pm 2.0^{\mathrm{Aa}} \\
25 \pm 1.0^{\mathrm{Ba}}\end{array}$ & $\begin{array}{l}52 \pm 1.0^{\mathrm{Ab}} \\
50 \pm 1.5^{\mathrm{Ab}} \\
47 \pm 1.0^{\mathrm{Bb}}\end{array}$ & $\begin{array}{l}80 \pm 0.5^{\mathrm{Ac}} \\
70 \pm 1.1^{\mathrm{Bc}} \\
60 \pm 1.0^{\mathrm{Cc}}\end{array}$ \\
\hline $40 \% E E$ & $\begin{array}{c}1 \\
0.5 \\
0.125\end{array}$ & $\begin{array}{l}0 \pm 0^{\mathrm{Aa}} \\
0 \pm 0^{\mathrm{Aa}} \\
0 \pm 0^{\mathrm{Aa}}\end{array}$ & $\begin{array}{l}30 \pm 1.0^{\mathrm{Ab}} \\
20 \pm 2.0^{\mathrm{Bb}} \\
10 \pm 2.0^{\mathrm{Cb}}\end{array}$ & $\begin{array}{l}42 \pm 1.0^{\mathrm{Ac}} \\
31 \pm 2.0^{\mathrm{Bc}} \\
22 \pm 0.5^{\mathrm{Cc}}\end{array}$ \\
\hline $50 \% E E$ & $\begin{array}{c}1 \\
0.5 \\
0.125\end{array}$ & $\begin{array}{c}10 \pm 0^{\mathrm{Aa}} \\
0 \pm 0^{\mathrm{Ba}} \\
0 \pm 0^{\mathrm{Ba}}\end{array}$ & $\begin{array}{l}38 \pm 1.1^{\mathrm{Ab}} \\
27 \pm 1.0^{\mathrm{Bb}} \\
25 \pm 0.5^{\mathrm{Bb}}\end{array}$ & $\begin{array}{l}80 \pm 1.0^{\mathrm{Ac}} \\
69 \pm 2.0^{\mathrm{Bc}} \\
60 \pm 1.5^{\mathrm{Cc}}\end{array}$ \\
\hline $60 \% E E$ & $\begin{array}{c}1 \\
0.5 \\
0.125\end{array}$ & $\begin{array}{l}16 \pm 1.5^{\mathrm{Aa}} \\
10 \pm 1.0^{\mathrm{Ba}} \\
07 \pm 2.0^{\mathrm{Ca}}\end{array}$ & $\begin{array}{l}40 \pm 1.0^{\mathrm{Ab}} \\
30 \pm 1.0^{\mathrm{Bb}} \\
20 \pm 1.0^{\mathrm{Cb}}\end{array}$ & $\begin{array}{l}62 \pm 1.1^{\mathrm{Ac}} \\
55 \pm 0.5^{\mathrm{Bc}} \\
40 \pm 1.5^{\mathrm{Cc}}\end{array}$ \\
\hline $70 \% E E$ & $\begin{array}{c}1 \\
0.5 \\
0.125\end{array}$ & $\begin{array}{c}18 \pm 2.0^{\mathrm{Aa}} \\
15 \pm 0.5^{\mathrm{Ba}} \\
12 \pm 2.0^{\mathrm{Ca}}\end{array}$ & $\begin{array}{l}40 \pm 2.0^{\mathrm{Ab}} \\
32 \pm 1.5^{\mathrm{Bb}} \\
27 \pm 1.0^{\mathrm{Cb}}\end{array}$ & $\begin{array}{l}52 \pm 1.0^{\mathrm{Ac}} \\
48 \pm 1.0^{\mathrm{Bc}} \\
35 \pm 1.5^{\mathrm{Cc}}\end{array}$ \\
\hline $80 \% E E$ & $\begin{array}{c}1 \\
0.5 \\
0.125\end{array}$ & $\begin{array}{l}40 \pm 1.5^{\mathrm{Aa}} \\
35 \pm 1.0^{\mathrm{Ba}} \\
30 \pm 1.0^{\mathrm{Ca}}\end{array}$ & $\begin{array}{l}65 \pm 0.5^{\mathrm{Ab}} \\
60 \pm 2.0^{\mathrm{Bb}} \\
52 \pm 2.0^{\mathrm{Cb}}\end{array}$ & $\begin{array}{l}80 \pm 2.0^{\mathrm{Ac}} \\
72 \pm 1.1^{\mathrm{Bc}} \\
65 \pm 1.0^{\mathrm{Cc}}\end{array}$ \\
\hline $100 \% E E$ & $\begin{array}{c}1 \\
0.5 \\
0.125\end{array}$ & $\begin{array}{l}18 \pm 0.5^{\mathrm{Aa}} \\
15 \pm 1.0^{\mathrm{Ba}} \\
12 \pm 1.0^{\mathrm{Ca}}\end{array}$ & $\begin{array}{l}42 \pm 2.0^{\mathrm{Ab}} \\
40 \pm 1.5^{\mathrm{Ab}} \\
35 \pm 1.5^{\mathrm{Bb}}\end{array}$ & $\begin{array}{l}80 \pm 0.5^{\mathrm{Ac}} \\
75 \pm 1.5^{\mathrm{Bb}} \\
70 \pm 1.1^{\mathrm{Cc}}\end{array}$ \\
\hline
\end{tabular}

$\mathrm{HE}$, hexanes extract; $\mathrm{AE}$, aqueous extract; $\mathrm{ME}$, methanolic extract; $\mathrm{EE}$, ethyl acetate extract. ${ }^{\mathrm{A}-\mathrm{C} V a l u e s}$ in columns having same upper-case letters are not significantly different $(\mathrm{P}<0.001)$; ${ }^{\mathrm{a}-\mathrm{C}} \mathrm{Calues}$ in rows having same lower-case letters are not significantly different $(\mathrm{P}<0.001)$.

Table 6. Median lethal concentration $\left(\mathrm{LC}_{50}\right)$ of different extracts and ethyl acetate fractions of T. baltistanicum.

\begin{tabular}{lccc} 
Fractions & $24 \mathrm{~h}$ & $\mathrm{LC}_{50}(95 \mathrm{\% CL})$ \\
$\mathbf{4 8 \mathrm { h }}$ & & $72 \mathrm{~h}$ \\
$H E$ & $0.2798(5.0428-3.1828)$ & $0.4023(3.2563-0.5825)$ & $0.0346(1.1785-0.0000)$ \\
$A E$ & $0.2713(4.46-2.6567)$ & $0.1591(1.4534-0.3959)$ & $0.0774(0.0871-0.0001)$ \\
\hline$M E$ & $0.1206(2.6777-1.8763)$ & $0.3456(2.4016-0.1047)$ & $0.3456(2.4016-0.1047)$ \\
$20 \% E E$ & $0.6076(6.2505-2.1918)$ & $0.6076(6.2505-2.1918)$ & $0.1871(0.8903-0.0094)$ \\
\hline $30 \% E E$ & $0.2497(2.6424-0.9744)$ & $0.2497(2.6424-0.9744)$ & $0.0772(0.1281-0.0013)$ \\
$40 \% E E$ & - & $0.2497(2.6424-0.9744)$ & $0.1356(1.6248-0.7189)$ \\
\hline $50 \% E E$ & $0.1356(1.6248-0.7189)$ & $0.6076(6.2505-2.1918)$ & $0.6076(6.2505-2.1918)$ \\
$60 \% E E$ & $0.6076(6.2505-2.1918)$ & $0.6076(6.2505-2.1918)$ & $0.1179(0.5665-0.1369)$ \\
\hline $70 \% E E$ & $0.1474(3.289-2.3095)$ & $0.1981(2.2777-0.9611)$ & $0.1713(1.3773-0.2387)$ \\
$80 \% E E$ & $0.5045(8.6175-5.264)$ & $0.2161(0.6534-0.0029)$ & $0.1159(0.113-0.0001)$ \\
\hline $100 \% E E$ & $0.2554(5.0762-3.3704)$ & $0.2389(3.2301-1.6423)$ & $0.0598(0.1504-0.0085)$ \\
\hline
\end{tabular}


M. incognita, Pratylenchus, Aphelenchoides and Helicotylenchus. The present finding agrees with those studies carried out earlier that $U$. dioica actively inhibited insect growth but in literature we could not find nematocidal activity of $U$. dioica against $M$. incognita. In this study, the aqueous extract of the leaves, roots, and stems of $U$. dioica effectively controlled the larvae of $M$. incognita whereas, the leaves extract showed more pronounced activity than that of the roots and stems. Sophora mollis is widely used as a pesticide and insecticide (Khan et al., 2011; Bazmi et al., 2014; Jabeen et al., 2015). Sophora flavescens possesses varied percentage of pesticidal activity against red spider mites. This study provides the first report about the nematocidal activity of $S$. mollis against $M$. incognita.

The present study showed that the aqueous and the methanolic extracts of E. intermedia (aerial parts) and the aqueous extracts of the roots showed the best resistance to $M$. incognita at different conc. whereas aqueous extracts was found more effective than the methanolic extracts. This is the baseline study for the first time about the nematocidal activity of $E$. intermedia against the larvae of M. incognita. However, Iqbal et al. (2010) reported the pesticidal activity of E. intermedia against Tribolium castaneum. Moreover, E. sinica has also exhibited potential antifungal activity against Alternaria panax, Phytophthora cactorum, Rhizictonia solani, Fusariom solani and Ustilago coicis, due to the presence of certain essential oils (Shu-tong et al., 2001). Literature study shows that pyrethrum, rotenone, neem, and essential oils are the most commonly used insecticides obtained from plants sources. Pyrethrum is obtained from flower of Tanacetum cinerariaefolium which contains $20-25 \%$ pyrethrins as an active component having pesticidal property. Pyrethrum acts in the similar fashion as synthetic pesticide DDT, blocking sodium gates and acts as a neurotoxin. Pyrethrum as an active pesticide was introduced in $17^{\text {th }}$ century. The organic extracts of Tanacetum baltistanicum has been reported to possess insecticidal properties against few common insect pests (Ismail et al., 2014). The results presented in Table 3 indicate that $M E, H E, E E$, and $A E$ of $T$. baltistanicum have $80 \%$ inhibitory activity on the growth of $M$. incognita. The active fractions of T. baltistanicum were comparable to each other showing the excellent activity against root-knot nematodes. We are not sure about the exact mechanism and the mode of the action of the certain plant extracts on root-knot nematodes, but it was found that the aqueous polar extracts showed the best activity as compared to lest polar fractions. It means that some lipophilic, polar oxygenated secondary metabolites from the plant may involve damaging the cytoplasm of the nematode cells causing toxicity to enzyme protein structure by the functional group interaction. There may be multiple factors for the nematocidal activity of the plant extracts which can be revealed through structure activity relationship of compounds present in these extracts. Korayem et al. associated the nematocidal activity of the plant extracts with its AChE inhibition activity (Korayem et al., 1993).

We recommend in-vivo testing of the active extracts, which have been never reported yet to promote the green practices for sustainable development in agriculture and the protection of the environment.

\section{Conclusions}

The investigation on green pesticides from natural sources is fundamentally important for the development of new botanical pesticides, especially in view of the vast worldwide flora. Based on the results presented in this paper, the $E E$ of $T$. baltistanicum, the $A E$ and $M E$ of the bulb of $A$. sativum, $A E$ of $S$. mollis, $A E$ of aerial parts of $E$. intermedia and the leaves, roots, and stems of $U$. dioica offers an opportunity for new botanical nematicides. Based on earlier findings on some other plant species and the present screening on selected plant species, we reached to the recommendations that medicinal plants extracts can be the best alternatives to the conventional nematicides. These plants may offer an alternative source for the control of certain nematodes without any negative impact on consumer health and the environment. However, more detailed studies are needed to identify and evaluate the active components and mechanism of action of these plant extracts to replace some of the existing toxic chemicals available in the market.

\section{References}

Abbas S, Dawar S, Tariq M, Zaki MJ, 2009. Nematocidal activity of spices against Meloidogyne javania (Treub) chitwood. Pak. J. Bot. 41:2625-32.

Adebayo SE, Toba AS, Prsper OC, Akeem OA, Ndaginna AI, 2014. Pesticidal plants diversity, status and uses in North Central Nigeria. Acad. Arena. 6:48-57.

Ahmad F, Rather MA, Siddiqui MA, 2010. Nematocidal Activity of Leaf Extracts from Lantana camara L. against Meloidogyne incognita (Kofoid and White) Chitwood and its use to Manage Roots Infection of Solanum melongena L. Braz. Arch. Biol. Technol. 53:543-8.

Amoabeng BW, Gurr GM, Gitan CW, Stevenson PC, 2014. Cost: benefit analysis of botanical insecticides uses in cabbage: Implications for smallholder farmers in developing countries. Crop Prot. 57:71-6.

Amonrar SV, Reeves EL, 1970. Mosquito control with active principle of Garlic, Allium sativum. J. Econ. Entomol. 63:1172-5.

Andrey V, Pico Y, 2004. Determination of pesticides and their degradation products in soil: critical review and comparison of methods. Trends Anal. Chem. 23:10-1.

Attia S, Grissa K, Lognay G, Mailleux AC, 2013. A review of the major biological approaches to control the worldwide pest Tetranychus urticae (Acari: Tetranychidae) with special reference to natural pesticides. J. Pest Sci. 86:361-86.

Bazmi RR, Javed I. Salmani UG, Razi MT, Rasool N, 2014. Analgesic and anti-inflammatory activity of Sophora mollis (Leguminosae) leaves and stem extracts in Mice. Int. J. Pharm. Phytopharm. Res. 3:374-7.

Chaudhary KK, Haile A, Ayresea ZG, Semereab G, Weldegergish T, 2013. Nematocidal activity of Eritrean weed plants against the root-knot nematode Meloidogyne incognita. Nematropica. 43:207-15.

Dang QL, Kwon HR, Choi YH, Choi G. Jang KS, Park MS, et al, 2010. Nematocidal activity against Bursaphelenchus xylophilus of isobtusilactone A isolated from Persea americana. Nematology. 12:247-53.

Echeverrigaray S, Zacaria J, Beltrão R, 2010. Nematocidal Activity of Monoterpenoids Against the Root-Knot Nematode Meloidogyne incognita. Nematology. 100:199-203.

Ferris H, Zheng L, 1999. Plant sources of chines herbal remedies: Effects on Pratylenchus vulnus and Meloidogyne javaniaca. J. Nematol. 31:241-63.

George DR, Finn RD, Graham KM, Sparagano OA, 2014. Present and future potential of plant-derived products to control arthropods of veterinary and medical significance. Parasit. vectors. 
7:28-40.

Gilani SA, Qureshi RA, Gilani SJ, 2006. Indigenous uses of some important Ethno medicinal herbs of Ayubia National Park, Abbottabad, Pakistan. Ethnobotanical Leaflets. 10:285-93.

Hubert GYJ, Julienn N, Charles DD, Daniel F, Sandrine PT, Romain FF, Henry AZP, 2013. Antifungal potential and phytochemical analysis of extracts from seven Cameroonian plants against late blight pathogen phytophora infestans. Int J Current Microbiol App. Sci. 2:140-54.

Iqbal J, Qayyum A, Mustafa SZ, 2010. Repellent effect of ethanol extracts of plant material on Tribolium Castaneum (Herbst) (Tenebrionidae: Coleoptera). Pak. J. Zool. 42:81-4.

Ismail M, Hussain F, Ali S, 2014. Botanical pesticide and insect repellent prepared from Tanacetum baltistanicum endemic to Gilgit-Baltistan. J. Biodiversity Environ. Sci. 5:128-35.

Jabeen N, Ajaib M, Siddiqui MF, Ulfat M, Khan BA, 2015. Survey of ethnobotanically important plants of Ghizer, GilgitBaltistan. FUUAST J. Biol. 5:153-60.

Jacobsen RE, Fantke P, Trapp S, 2015. Analysing half-lives for pesticide dissipation in plants. SAR QSAR Environ. Res. 26:325-42.

Kaberia DK, 2007. Participatory action research and testing the effectiveness of stinging nettle as a biopesticide in Kenya. A thesis submitted in partial fulfilment of the requirement of degree of Master of Science in natural resources management, University of Wisconin, Kenya.

Kedia A, Prakash B, Mishra PK, Singh P, Dubey NK, 2015. Botanicals as eco-friendly biorational alternatives of synthetic pesticides against Callosobruchus ssp (Coleoptera:Bruchidae). Food Sci. Technol. 15:1239-57.

Khan B, Abukadir A, Qureshi R, Mustafa G, 2011. Medicinal uses of plants by the inhabitants of Khunjerab national park, Gilgit, Pakistan. Pak. J. Bot. 43:2301-10.

Khan MZ, Khan B, Ahmad E, Khan G, Ajmal A, Ali R, 2014. Abundance, distribution, and conservation of key ungulate species in Hindu Kush, Karakoram, and Western Himalayan $(\mathrm{HKH})$ mountain range of Pakistan. Int. J. Agric. Biol. 16:1050-8.

Korayem, Am, Hasabo,SA, Ameen, HH, 1993. Effects and mode of action of some plant extracts on certain plant parasitic nematodes. Anz. Schadlingskde., Pflanzensschutz, Umweltschutz. 66:32-6.

Kumar NS, Simon N, 2016. In-vitro antibacterial activity and phytochemical analysis of Gliricidia sepium (L.) leaf extracts. J. Pharm. Phytochem. 5:131-3.

Kunwar RM, Adhikari N, 2005. Ethnomedicine of Dolpa district, Nepal: The plants, their vernacular names and uses. Lyonia. 8:43-9.

Mackeen MM, Ali AM, Abdullah MA, Nasir RM, Mat NB, Razak AR, 1997. Antinematodal activity of some Malaysian plants extracts against the pine wood Nematode, Bursaphelenchus xylophilus. Pestic. Sci. 51:165-70.

Martins JG, Chavez AA, Waliszewski SM, Cruz AC, Fabila MMG, 2013. Extraction and clean-up methods for organochlorine pesticides determination in milk. Chemosphere. 92:233-46.
Masangwa JIG, Aveling TAS, Kritzinger Q, 2013. Screening of plant extracts for antifungal activities against Colletorichum species of common bean (Phaseolus vulgaris L.) and Cowpea (Vigna unguiculata (L.) Walp). J. Agric. Sci. 151:482-91.

Nabile, Wakeil EL, 2013. Botanical pesticides and their mode of action. Gesunde Pflanzen. 65:125-49.

Nassar AMK, 2016. Effectiveness of silver nano particles of extracts of Urtica urens (Urticaceas) against root-knot nematode Meloidogyne incognita. Asian J. Nematol. 5:14-9.

Nath G, Singh K, 2015. Combined effect of Vermiwash with Biopesticides against infestation of Pod borer (Helicoverpa armigera Hub.). Int. J. Zool. Invest. 1:40-51.

Odeyemi OO, Arannilewa ST, Akinneye JO, Ashamo MO, 2013. Protectability of nine Nigerian medicinal plants against Cowpea beetle, Callosobruchus maculatus (Feb.) (Coleoptera: Bruchiidae) in storage. Arch. Phytopath. Plant Prot. 46:1376-83.

Priya VKJ, Gopalan R, 2015. A survey on some poisonous plants and their medicinal values in Dhoni forest, Palakkad, Kerala, India. Int. J. Curr. Microbiol. App. Sci. 4:234-9.

Roy S, Handique G, Muraleeduaran N, Roy SM, Mukhopadhyay A, Baby A, 2016. Use of plant extracts for tea pest management in India. App. Microbiol. Biotech. 100:4831-44.

Shu-tong W, Xiao-yan W, Jun-ling L, Ke-qiang C, 2001. Screening of Chinese herbs for the Fungi toxicity against Phytophthora infestans. J. Agric. Uni. Hebei. 24:101-7.

Sola P, Mvumi B, Ogend, JO, Mponda O, Kamanula JF, Nyirenda $\mathrm{SD}$, et al, 2014. Botanical pesticides production, trade and regulatory mechanism in sub Saharan Africa: making a case for plant-based pesticidal product. Food Sec. 6:369-84.

Tapwal A, Nisha, Garg S, Gautam N, Kumar R, 2011. In-vitro antifungal potency of plant extracts against five phytopathogens. Braz. Arch. Biol. Technol. 54:1093-8.

Tijjani A, Adebitan SA, Gurama AU, Aliyul N, Haruna SG, Mohammad GU, 2014. In-vitro and in-vivo efficacy of some plant extracts for the control of tomato fruit Rot caused by Aspergillus Flavus. Int. J. Sci. Res. Pub. 4:1-5.

Ujvary I, 2000. Semi-natural products and related substances as alleged botanical pesticides. Pest Manag. Sci. 56:703-5.

Uy MM, Villazorda MGL, 2015. The antioxidant properties of the Philippines medicinal plants Cassia sophera Linn, Derris elliptica Benth, Ficus minahassea Tesym. and Leucosyke capitellata Weed. Adv. Agric. Bot. Int. J. Biof. Soc. 7:150-6.

Varma J, Dubey NK, 1999. Prospective of botanicals and microbial products as pesticides of tomorrow. Curr. Sci. 76:172-9.

Zadoks JC, Waibel H, 2000. From pesticides to genetically modified plants, history, economies, and politics. Nethl. J. Agric. Sci. 48:125-49.

Zubari SIB, 2006. The yield and biological activity $\left(\mathrm{LC}_{50}\right)$ of rotenone extracted from Derris elliptica. A thesis submitted in the fulfilment of the requirements for the award of the degree of Master of Engineering (Bioprocess), Faculty of Chemical and Natural Resources Engineering, University Technology Malaysia, Malaysia. 